1

2

3

\title{
Glacial and paraglacial history of the Troutbeck Valley, Cumbria, UK: integrating airborne LiDAR, multibeam bathymetry, and geological field mapping
}

\author{
Helen Miller, ${ }^{\mathrm{a}, *}$, Carol J. Cotterill ${ }^{\mathrm{b}}$, Tom Bradwell ${ }^{\mathrm{b}}$ \\ ${ }^{a}$ National Oceanography Centre, Southampton, University of Southampton, European \\ Way, Southampton, SO14 3ZH, United Kingdom \\ ${ }^{b}$ British Geological Survey, Murchison House, West Mains Road, Edinburgh, EH9 3LA, \\ United Kingdom
}

\begin{abstract}
High resolution airborne LiDAR (Light detection and ranging) and multibeam bathymetry data, supplemented by geomorphological and geological field mapping are used to derive the glacial and post-glacial history of Troutbeck Valley (English Lake District) at a catchment scale. The results inform wider regional and ice sheet wide glacial reconstructions and demonstrate the effectiveness of an integrated approach combining geomorphological and sedimentological signatures with remote sensing. The holistic catchment approach is used to reconstruct palaeo-ice flow and behaviour of a small part of the last British and Irish Ice Sheet, identifying a series of depositional environments that accompanied both ice advance, ice retreat and post-glacial deposition within the Lake District. Drumlins are mapped in the lower catchment and show multiple regional (wider-extent) ice flow events and a
\end{abstract}

\footnotetext{
*Corresponding author

Email addresses: Helen.Miller@noc.soton.ac.uk (Helen Miller), cjcott@bgs.ac.uk (Carol J. Cotterill), tbrad@bgs.ac.uk (Tom Bradwell)
} 
sedimentology consistent with deposition by lodgement processes during the Main Late Devensian Stadial. Other subglacial deposits include till sequences formed under variable basal conditions beneath an advancing ice mass. Retreat features include a suite of recessional moraines formed by still-stands or small readvances of an outlet glacier. Following deglaciation, major sediment redistribution led to formation of a large fan delta via paraglacial and post-glacial fluvial sedimentation. This study indicates that an integrated approach, using geomorphology, sedimentology and remote sensing on a catchment scale, is capable of deriving a more in-depth understanding of regional ice sheet reconstructions and highlights the complexity of palaeoice sheet dynamics at a range of spatial scales.

Keywords: glacial geomorphology, sedimentology, catchment scale, Lake District, Troutbeck Valley

\section{Introduction}

During the most recent Devensian Glaciation, the Lake District formed a major independent, upland centre of ice dispersion (Ballantyne et al., 2009) within the central sector of the last British and Irish Ice Sheet (BIIS), characterised by considerable complexity and dynamic ice-flow (Hubbard et al., 2009). Recent reconstructions of the complex geomorphological ice-flow signature within the central sector of the BIIS combine glacial geomorphological mapping and landform evidence with relative and absolute dating constraints to provide a broad template of ice-flow dynamics (Livingstone et al., 2008; Evans et al., 2009; Clark et al., 2012; Livingstone et al., 2012). A number of studies have used geomorphological mapping and sedimentological evidence 
in the English Lake District to reconstruct regional ice extent and flow dynamics of the last BIIS (Clark et al., 2004; Wilson, 2004; Hughes et al., 2010) and the the Younger Dryas ice masses (YD; equivalent to the Loch Lomond Stadial or Readvance) (Sissons, 1980; Wilson and Clark, 1998, 1999; McDougall, 2001; Brown et al., 2011). Within Windermere, England's largest lake, recent research has reconstructed the deglaciation history of the lake basin based on high-resolution seismic data (Vardy et al., 2010; Lowag et al., 2012; Pinson et al., 2013) however, little research has focused specifically on the glacial history of valley catchments draining into Windermere. This paper aims to build on existing research within Windermere, using high resolution LiDAR and multibeam bathymetry data supplemented by geomorphological and geological fieldwork to derive the Late-Quaternary history of a glaciated valley at a catchment scale. The results are used to investigate whether a catchment analysis can be used to inform wider regional and ice sheet wide glacial reconstructions.

\subsection{Regional Setting}

Windermere is the largest natural lake in England and is divided into a North and South Basin separated by a basement high and a shallow area with numerous small islands. Troutbeck Valley is located to the east of the North Basin within the Windermere catchment, north of Bowness in Windermere, and extends approximately $11 \mathrm{~km}$ NW towards the Cumbrian Mountains (Fig. 1). The Troutbeck (river) is an important fluvial input in the North Basin and has a catchment size of $26 \mathrm{~km}^{2}$ (calculated from hydrological analysis in ArcGIS using NEXTMap data). Although Troutbeck is hydrologically subordinate to other inflows in the North Basin, it is sed- 
imentologically more important owing to the trapping efficiency of lakes in other feeder valleys, such as Great Langdale and Easedale-Rydal. The upper reaches are located in upland terrain and have been realigned, with embankments and full bank protection in some areas. The lower reaches are less modified and are constrained within a deep valley which limits floodplain extents. A recent Fluvial Audit identified a number of unvegetated temporary bars storing a large volume of coarse sediment in the system (Barlow et al., 2009a,b). Troutbeck Valley is classified as a Site of Special Scientific Interest due to the large variety of habitats found, particularly the range and extent of flushed grassland and fen vegetation types (Natural England). The geological setting of Troutbeck (glacially eroded river valley system with many outcrops of bedrock and deposits of glacial till and boulder clay) provides a range of habitats for several vegetation types.

Figure 1: Location of study area, showing the Troutbeck catchment, Windermere, Haweswater Reservoir and previously published glacier reconstructions digitised from Sissons (1980) and Wilson and Clark (1998). Onshore DEM and catchment area calculated using 5m resolution NEXTMap data. Insert shows location map of the study area in relation to the Lake District and the British Isles, with the location of Great Langdale, Easedale, Rydal, Grasmere, Stock Ghyll and Troutbeck. Boxed area shows the location of the enlarged panel in Figure 2.

Troutbeck Valley can be described as a glacially deepened valley eroded during successive Quaternary Glaciations, with deposits of glacial till (clayey, silty, sandy gravel) on the valley floor and valley sides (BGS, 1998). Areas of ice scoured and in places weathered Ordovician (Borrowdale Volcanic Group) and Silurian (Windermere Supergroup) bedrock frequently crop out along the 
valley bottom (Millward et al., 2010). In the upland fells a thin discontinuous cover of glacial till occurs on ice scoured bedrock. Other glacial deposits include a number of morainic deposits within the valley formed by successive glacial retreat, and a drumlinised till sheet extending north and south beyond the lower reaches of the river. A number of drumlins have been mapped by Hughes et al. (2010) and are identifiable as elongate elliptical-shaped features which form large characteristic streamlined hills (Pearsall and Pennington, 1973). Alluvial deposits of gravel, sand, silt and clay are also found in patches on the valley floor and at the mouth of the river in the form of a prominent fan delta (BGS, 1998).

During the Devensian glaciation, the Lake District formed a major upland ice-dispersal centre of the BIIS, characterised by warm-based glaciers up to $800 \mathrm{~m}$ thick (Ballantyne et al., 2009). The glacially eroded landforms of the central mountains include well developed corries, striated and glacially modified bedrock and overdeepened valleys such as Windermere and Coniston Water (Pennington, 1978). Glacial landforms (such as drumlins, eskers and moraines) mantle much of the lowlands in till, interstratified in places with laminated clays, silts and sands (Pearsall and Pennington, 1973; Pennington, 1978).

BIIS retreat following the Last Glacial Maximum (LGM), led to complete deglaciation of the Lake District by the onset of the Allerød interstadial (known locally as the Windermere Interstadial). Lithostratigraphical, biostratigraphical, chronostratigraphical and geochemical evidence from Low Wray Bay in Windermere has established several ages for the transition to interstadial conditions (Pennington, 1943, 1947; Coope, 1977; Pennington 
et al., 1977; Huddart and Glasser, 2002). The ages are based on $2-7 \mathrm{~cm}$ bulk samples from organic sediment overlying glacigenic units, targeting deposits containing pollen and fauna indicative of tundra type environments. The radiocarbon dates have been calibrated by Knight (2001)(17.6 \pm 0.4 cal. Kyrs BP), Vincent et al. (2010) (17.7 \pm 1.0 cal. Kyrs BP) and Hughes et al. (2011) (17.7 \pm 0.4 cal. Kyrs BP) using CALIB v4.2, OxCal v4.0 and CALIB v6.0 respectively (calibration curves ITCAL04, ITCAL09). Although these dates record the onset of organic sedimentation in the catchment rather than deglaciation, they provide a maximum constraint for deglaciation to after 18-17 ka BP. These dates broadly agree with cosmogenic ${ }^{36} \mathrm{Cl}$ exposure ages from ice-moulded bedrock in the Wasdale valley (NW of Windermere), suggesting a maximum age constraint for deglaciation to the mountain core of the Lake District after 18.1 ka BP (Ballantyne et al., 2009).

In the central and southern Lake District, there are very few identifiable landforms which can be correlated with local BIIS ice retreat (Hughes et al., 2010). As a result, deglaciation was thought to have been rapid, characterised by ablation and downmelting in situ in response to rapid climate amelioration (Pennington, 1978). More recent studies have identified recessional moraines in Windermere (Pinson et al., 2013), upper Eskdale (Wilson, 2004) and to the south of Windermere (Clark et al., 2004) which are correlated with late stage residual BIIS retreat. In Windermere, the moraines are visible in the multibeam bathymetry as major ridges which cross-cut the basin creating a stepped topography (Miller et al., 2013). These glaciogenic landforms are thought to have formed by still-stands and/or small readvances indicating active ice during glacial retreat rather than in situ stagnation and 
downwasting.

Following the Allerød interstadial, ice readvanced in the form of small valley and cirque glaciers during the YD between c. 13-11 ka BP (Coope, 1977; Pennington et al., 1977). The extent of YD glaciers to the north of Troutbeck has been inferred by Sissons (1980) and Wilson and Clark (1998) based on the location of hummocky moraines, flutes and boulder limits (Fig. 1). These glacier reconstructions suggest the Troutbeck catchment was not glaciated during the YD, and consequently the glacial deposits within the valley are thought to relate to retreat of the BIIS prior to the YD.

\section{Methodology}

\section{1. $\operatorname{LiDAR}$}

LiDAR (Light detection and ranging) is an optical remote sensing technology that uses a laser to measure the distance between a sensor (normally airborne) and the ground surface, providing high resolution terrain data. The LiDAR dataset used in this study was collected by the Environment Agency, with the majority of data captured in 2008 , covering a total area of $214.5 \mathrm{~km}^{2}$. The upper reaches of Troutbeck Valley extend beyond the LiDAR data coverage and are not examined in this study. The $2 \mathrm{~m}$ resolution composite Digital Terrain Model and Digital Surface Model is derived from a combination of all data at $2 \mathrm{~m}$ or better resolution which has been merged and re-sampled to give the best possible coverage in metres above Ordnance Datum Newlyn. The original laser measurements were transformed from British National Grid format WGS 84 to OSGB 36 using the OSTN02/OSGM02 transformation algorithms provided by Ordnance Survey. ArcGIS was used to convert the 
raw data to UTM (WGS 84 datum) and mosaic together the files to create a seamless Digital Elevation Model (DEM) for analysis.

Onshore terrain data from NEXTMap Britain, a national IfSAR (interferometric synthetic aperture radar) digital elevation database, was used at $5 \mathrm{~m}$ spatial resolution to supplement the LiDAR dataset and used for hydrological analysis in ArcGIS to calculate catchment size. IfSAR is an airborne radar mapping system which uses pairs of high resolution SAR images to derive topographic information using phase interferometry methods. Both LiDAR and IfSAR generate independent measurements of terrain elevation on a dense grid of sample points providing a high spatial resolution DEM over a large area.

\subsection{Multibeam}

The swath bathymetry survey in Windermere was undertaken in September 2010 on the British Geological Survey (BGS) vessel R/V White Ribbon using a SIMRAD Kongsberg EM3002D dual head system providing 100\% coverage of both the North and South Basin to $5 \mathrm{~m}$ water depth, as detailed in Miller et al. (2013). Post processing was completed using CARIS HIPS/SIPS and filtered data was gridded at $1 \mathrm{~m}$ resolution, corrected to Ordnance Datum Newlyn using lake level data from an electronic gauge taken at continuous 15 minute intervals to an accuracy of $\pm 2 \mathrm{~mm}$.

\subsection{Field Measurements and Digital Mapping}

A field survey of Troutbeck Valley and the surrounding area was undertaken in March 2012. The morphology of the landscape was pre-assessed 
using the 2m LiDAR DEM and BGS large scale geological maps. The distribution and shape of glacial landforms were mapped and recorded digitally using a ruggedised tablet PC with a BGS customised version of Arc 9.0. Clast fabric data (A-B plane) and lithology was recorded at three locations using a compass-clinometer (Fig. 2). Grain size analysis (PSA) was completed on sediment samples from each site according to British Standard 812-103.1 (BSI, 1985) (see Appendix for details). Additional geological data (including striae, field notes and section logs) were recorded in the field. The LiDAR and multibeam data were merged together in ArcGIS, converted using the VSI Converter and imported into GeoVisionary 1.0.4.0. Aerial photographs, OS Maps and the bedrock geology were added as image layers to aid analysis and interpretation. Glacial landforms were digitised, saved as shape files and imported into ArcGIS.

Figure 2: Geomorphological map of Troutbeck Valley with ice flow directions, overlain on $2 \mathrm{~m}$ resolution LiDAR data and $1 \mathrm{~m}$ resolution multibeam bathymetry data displayed as hillshade layers to show shaded relief surface. Onshore NEXTMap data is used in areas where there is no LiDAR coverage, and the locations of diamict samples (A, B, C) are shown.

\section{Results}

\subsection{Geomorphological Mapping: Troutbeck Valley}

A drumlinised till sheet with more than 20 well developed, generally elongated drumlins is mapped to the east of Windermere, extending across the fan delta and to the north and south beyond the fan delta (Fig. 2). The drumlins are morphologically distinct, range in length from 100-500m and 
are generally composed of strongly ice-flow moulded till. Drumlin axes trend mainly NNE to SSW to the south of the fan delta, and locally trend NW to SE immediately north of the fan. At the fan apex, Troutbeck has cut into the southern flank of a drumlin and has exposed a $2 \mathrm{~m}$ vertical section of glacial diamict (Figs. 2 and 3A \& C). The sedimentology of this diamicton is described in Section 3.2.1. In addition, 3 distinctive bedrock cored drumlins with a thin mantle of till are mapped on the drumlinised till sheet (Figs. 2 and $3 \mathrm{~A}-\mathrm{C})$.

Figure 3: Oblique overviews of Troutbeck alluvial fan delta, comprising merged LiDAR and multibeam datasets, with major aspects of fan morphology. Features labelled: A, fan apex; B, till bench; C, drumlin; D, river terraces; E, fan delta complex either side of main channel; F, main active channel; G, bedrock cored drumlin; H, debris flow; I, palaeo outflow; J, palaeo benches. Red star shows location of glacial diamict in Panel A and C, colour effect in upper right of Panel A is due to no LiDAR coverage in this area.

Glacial deposits spatially confined within the valley, including those comprising a suite of moraine ridges or forms are predominantly orientated NW to SE. The moraines are smeared on the valley side to the north of the river and extend up to $400 \mathrm{~m}$ in length (Fig. 2). Till benches, up to $1 \mathrm{~km}$ in length and $30 \mathrm{~m}$ high are also mapped within the valley bottom, and confine the river and limit the floodplain. Troutbeck has cut into two distinct till benches, exposing clean sections of glacial diamict (Fig. 2) which is further described in Sections 3.2.2 and 3.2.3.

Other mapped features include a large sub-aerial fan delta complex which extends into Windermere at the point where the river is no longer confined in a deep valley, defined as the fan apex (Fig. 3A \& C). The low angle 
fan is approximately $1.5 \mathrm{~km}$ in length, with a maximum width of $1.3 \mathrm{~km}$, and is composed of alluvial deposits of gravel, sand, silt and clay. Several river terrace levels are visible on the alluvial fan (Figs. 2 and 3A-C), and a number of palaeo benches are identified on the prograding fan front using the multibeam bathymetry (Fig. 3A-C). A large debris flow is also visible on the fan front, and palaeo outflow no longer associated with modern outwash is identified to the north of the river mouth (Fig. 3A-C).

\subsection{Sedimentology}

\subsubsection{Diamict $A$}

A massive, matrix-supported diamicton, approximately $0.6 \mathrm{~m}$ in vertical thickness is preserved along the northern bank of Troutbeck at the apex of the alluvial fan (Figs. 2 and 3A \& C). The grey, clast rich diamicton is overconsolidated, characterised by its strong fissility and strong pervasive fabric, and is interpreted as a shear fabric, with multiple cracks and subhorizontal fracturing. Abundant striated clasts, typically sub-rounded and bullet shaped are present within the diamicton (Fig. 4). Particle size analysis of the matrix shows a broad multi-modal grain size distribution with two distinct groups: fines are predominantly composed of very fine silt and the coarse fraction is dominated by medium and coarse gravel (Fig. 5A). Clast lithologies within the diamicton typify the bedrock geology, dominated by meta-sediment $(63 \%)$ and slate $(27 \%)$ originating from Silurian shales and flags, with smaller proportions of volcanic from the Borrowdale Volcanic Group (Fig. 6A). Striations are found on all clasts, regardless of lithology. Clast fabric analyses (Allmendinger et al., 2012) reveal a strong fabric with $67 \%$ of clasts clustering between $120-176^{\circ}$ with the majority of dips less than 
$35^{\circ}$ (Fig. 6A). The diamicton is directly overlain by a clast-supported cobble gravel unit with very little fines, separated by an erosional unconformity.

Figure 4: Exposures of Diamict A, just above stream level: (A) overview of exposure; (B) clean exposure $0.6 \mathrm{~m}$ high showing abundant lodged clasts, arrows indicate direction of clast dip, Dmm: Matrix-supported diamicton (massive); (C) the majority of clasts are sub-rounded and bullet shaped, with dips less than $35^{\circ}$. The location of the exposure is shown in Figure 2.

Figure 5: Particle size analysis of Diamict A, B and C represented as a frequency and cumulative plot. The size scale is based on the Wentworth scale (1922). For ease of visualisation, particle size distribution for each sample is separated into the fine fraction (upper panel) and the coarse fraction (lower panel) (see Appendix for details).

Figure 6: Upper panel: clast lithology analysis of Diamict A, B and C. Lower panel: clast fabric data (lower hemisphere, equal area stereonet projection) showing orientations of clasts from Diamict A, B and C and inferred palaeo-ice flow derived from the overall trend of the dipping clasts. Axis orientations consist of a bearing direction and dip (degrees); C $=$ conglomerate.

\subsubsection{Diamict $B$}

This diamicton is preserved as part of a $30 \mathrm{~m}$ high till bench along Troutbeck, located 1.9km upstream of Diamict A (Fig. 2). It is in the form of two exposures within the river bank, separated by a large slump of vegetated sediment (Fig. 7). The grey, matrix-supported diamicton is less consolidated than Diamict A, and is clast rich, with equal quantities of sub-rounded and sub-angular clasts. A number of clasts (57\%) are striated, regardless of 
lithology. Particle size analysis shows a multi-modal grain size distribution, dominated by very fine and medium silt within the fine fraction and a sand matrix within the coarse fraction (Fig. 5B). Clast lithologies are similar to Diamict A, and are dominated by meta-sediment (70\%) and slate (17\%) derived from Silurian shales and flags (Fig. 6B). Fabric measurements were taken from the upper and lower exposure, and reveal a moderately developed clast fabric with the majority of dips less than $50^{\circ}$ (Fig. 6B).

Figure 7: Exposures of Diamict B: (A) overview of two exposures, separated by a slump of vegetated sediment; (B) clean exposure with lodged clasts. The location of the exposure is shown in Figure 2.

\subsubsection{Diamict $C$}

This diamicton is preserved $50 \mathrm{~m}$ upstream of Diamict B within a $10 \mathrm{~m}$ high vegetated till bench along Troutbeck (Fig. 2). The river has cut into the till bench, and exposed a $2 \mathrm{~m}$ vertical section above stream level, approximately $15 \mathrm{~m}$ in length (Fig. 8). The exposed matrix-supported grey diamicton is less consolidated than in Diamict A, and is characterised by a number of high-angle $\left(>30^{\circ}\right)$ shear planes, and areas of fissure filling and sediment deformation. The diamicton is clast rich, with the majority of clasts (75\%) ranging from rounded to sub-rounded. Striations are found on many (38\%) clasts regardless of lithology. Particle size analysis is broadly similar to Diamict B (Section 3.2.2), characterised by a multi-modal grain size distribution with sharp peaks of fine, medium and very coarse silt. The coarse fraction is similarly dominated by a sand matrix with medium gravel (Fig. 5C). Clast lithologies are dominated by meta-sediment and slate, and there 
is a slightly higher proportion of volcanic clasts (15\%) within the diamicton compared to Diamict A and B (Fig. 6C). The diamicton has a weakly developed clast fabric with a wide range of dips (Fig. 6C).

Figure 8: Exposures of Diamict C, just above stream level: (A) overview of exposure, with Tom Bradwell standing in river for scale (from stream level, approximately $1.4 \mathrm{~m}$ high); (B) clean exposure with lodged clasts. The location of the exposure is shown in Figure 2.

\section{Interpretation and Glacial History}

\subsection{Ice flow: subglacial deposits}

Within the Windermere valley, drumlins are restricted to the low-lying drumlinised till-covered terrain east of the lake, where the valley widens and is not topographically confined. Drumlins represent the deformation, here of subglacial deposits, formed when a thick ice mass was moving southwards directed by topography (Pennington, 1978). We infer drumlin formation took place during the Main Late Devensian Stadial, when warm-based glaciers (up to $800 \mathrm{~m}$ thick) flowed south (Fig. 2), entering Windermere from the Great Langdale, Grasmere, Stock Ghyll and Troutbeck valley catchments (Fig. 1). The drumlins, some of which may be bedrock cored, formed parallel to ice movement, orientated in the direction of ice flow from the valleys of the Cumbrian Mountains during the last glaciation. Drumlins north of the fan are orientated NW to SE, suggesting that they were modified by ice flowing southwards from Great Langdale, Grasmere and Stock Ghyll and eventually towards the Irish Sea Basin. To the south of the fan near Bowness in Windermere, the orientation of drumlins (NNE to SSW) indicates a slight 
deflection of ice flow (Fig. 2). We infer that convergence of ice from the Troutbeck and northern Windermere catchments caused this slight shift in ice flow pattern.

Postglacial fluvial erosion has partially eroded a drumlin located at the apex of the fan delta, exposing Diamict A (Section 3.2.1) which is interpreted as a subglacial lodgement till deposited by the last BIIS during the Main Late Devensian Stadial. The till properties all suggest that material has been transported and comminuted at the base of a warm-based glacier consistent with deposition by subglacial processes, with deformation of the sub-ice bed a significant component of ice movement. The inferred palaeo-ice flow based on clast fabric data (Fig. 6A) suggests the drumlin was formed by a thick ice mass flowing southwards from Great Langdale, Grasmere and Stock Ghyll. The presence of large striated clasts within the lodgement till represents eroded material supplied during glacial transport, and suggests abrasion processes dominated.

Benches of glacial diamict in Troutbeck Valley (Fig. 2) are interpreted as subglacial deposits formed during the Main Late Devensian Stadial. Diamict $\mathrm{B}$ and $\mathrm{C}$ (Sections 3.2.2 and 3.2.3 respectively) are located within till benches, and are interpreted as subglacial till. The different diamicton properties give rise to the possibility that the till sequences in Troutbeck contain clast fabric signatures of different transport and depositional regimes at the icebed interface. In particular, clast fabric data from Diamict B suggests the till was formed under ice flowing from NW to SE, whereas the inferred palaeoice flow from Diamict $\mathrm{C}$ was from east to west (Figs. 2 and $6 \mathrm{~B} \& \mathrm{C}$ ). The matrix of Diamict B and C is dominated by sand derived from volcani- 
clastic bedrock, indicating glacial crushing processes were intense but not as sustained as further down-valley (Diamict A) where silt/clay predominates representing the final products of glacial comminution. This demonstrates the complexity of glacial reconstructions in formerly glaciated terrain and suggests the different subglacial tills were formed under different conditions beneath an advancing ice mass, influenced to greater or lesser degree by ice thickness, valley morphology and topographic slope.

\subsection{Deglaciation: ice marginal deposits}

BIIS ice retreat in Windermere is believed to have taken place after 1817 ka BP (Section 1.1) in the form of individually retreating outlet glaciers (Pinson et al., 2013). This style of deglaciation, through disintegration into a number of independent ice caps rather than reduction as a single mass agrees with observations of wider BIIS deglaciation (Clark et al., 2012; Livingstone et al., 2012). In Troutbeck, retreat of glacier ice took place in a NE direction. We infer the ice lobe (in the form of an ice-cap outlet glacier) retreated faster than the other confluenced glaciers (originating in Great Langdale, Easedale and Stock Ghyll to the north) because it was south facing and sourced at a lower altitude in the eastern fells with a smaller accumulation area above the ice-margin. The geomorphological evidence identifies a suite of moraines within Troutbeck Valley well beyond the published YD limit (Fig. 2). We interpret these features as recessional moraines, formed at the ice-margin by still-stands or small readvances of a glacier in Troutbeck Valley. These icemarginal positions were probably topographical pinning points during latestage retreat of the residual BIIS in Cumbria. This style of retreat supports the recent findings of Clark et al. (2004), Wilson (2004) and Pinson et al. 
(2013) who identified retreat moraines correlated with late stage residual BIIS retreat, formed during active glacier retreat by still-stands or small readvances.

\subsection{Paraglaciation and postglaciation: alluvial fan delta}

As the glacier retreated up Troutbeck Valley, a clast-supported coarsegrade cobble gravel unit was deposited at the then subaqueous mouth of Troutbeck infilling, at least in part, the drumlinised ground. The unit is interpreted as a high-energy outwash deposit, derived from melt-waters issuing from the retreating Troutbeck valley glacier (Section 3.2.1). Troutbeck Valley is believed to have been ice free prior to the onset of the Allerød interstadial (>15.5 ka BP) and glacier reconstructions suggest that the Troutbeck catchment was not glaciated during the YD (13-11 ka) (Fig. 1). The geomorphological evidence in the lower reaches of the valley is consistent with this interpretation, and the preserved glacial deposits suggest there has been no significant re-growth of ice following the main period of ice retreat. This suggests there was a relatively long ice-free period following deglaciation of the BIIS (around $16 \mathrm{ka}$ BP). We infer paraglacial processes and exposure of unstable or metastable sediment sources would have created a landscape liable to rapid and extensive modification, leading to major sediment redistribution and formation of a fan delta via further infilling around the drumlins. A large proportion of the fan would have formed soon after the valley became ice-free due to high sediment yields, particularly through slope readjustments resulting from glacial and deglacial influences (Ballantyne et al., 2009). Late Devensian paraglacial activity is observed throughout the Lake District, particularly NW of Troutbeck (Wilson, 2005; Wilson and Smith, 2006). In addi- 
tion, snow melt in this mountain catchment would have also led to extensive redistribution of the products of periglacial weathering, further building up the fan during the Late-glacial Interstadial and early Holocene.

Following ice retreat, fluvial activity played an important role in building up the fan delta, delivering sediment into the system. In particular, erosion of till benches is particularly seen in the lower reaches of the river where Diamict B and C are exposed (Sections 3.2.2 and 3.2.3 respectively). Palaeo terraces, palaeo outflow no longer associated with modern outwash and a large debris flow on the fan front (Fig. 3A-C) further provide a record of fluvial activity and fan development, and suggest the fan delta has prograded since late glacial ice retreat, forming a fan complex with multiple outflows which transferred sediment into the lake basin. River entrenchment and terracing (Fig. 2) of the pro-glacial fan delta was coincident with fan building, and indicates that the local base level has lowered a number of times during the Holocene possibly in response to changing lake levels. The present day Troutbeck fan delta continues to build as sediment flows into the system, particularly during flood events.

\section{Conclusions}

We derive the Late-Quaternary history of a glaciated valley catchment, using a combination of geomorphology, sedimentology and remote sensing. The results have been used to inform and complement existing glacial reconstructions within the central Lake District, and we demonstrate the complexity of the glacial signature in a single catchment. Our glacial reconstructions identify regional (wider-extent) ice flow events, seen in the orientation and 
morphology of drumlins on low ground. The sedimentology of till deposits within the Troutbeck Valley provides clast fabric signatures of subtly different former ice-flow transportation and deposition processes at the ice-bed interface, demonstrating the complexity of glacial reconstructions in formerly glaciated terrain. The suite of recessional moraines mapped within Troutbeck are believed to have formed by still-stands or small readvances of an outlet glacier during residual ice cap retreat. The Troutbeck alluvial fan delta is the major sediment sink and represents the largest single deposit in the catchment. The fan was formed by a combination of paraglacial and postglacial sedimentation, and is representative of the wider scale environmental response of the landscape following ice retreat in mountainous northern Britain. Our findings demonstrate that geomorphological and sedimentological signatures can be used effectively at a catchment scale to derive local glacial and environmental histories, and are a valuable tool to supplement ice sheet wide glacial reconstructions (e.g. Clark et al., 2012).

\section{Acknowledegments}

The authors acknowledge support of the Environment Agency and the Freshwater Biological Association. Helen Miller is a $\mathrm{PhD}$ student at the University of Southampton, and is partially supported by a BGS BUFI PhD studentship (reference S177, Determination of modern lacustrine, late-glacial and post-glacial environments and processes in glacial lake Windermere, UK). We thank Prof. Jonathan Bull from the University of Southampton, the crew and hydrographic surveyors of the R/V White Ribbon and BGS Marine Operations, the Windermere Lake Wardens, Martin Dodgson and Charlotte 
Thompson for their support. In addition, we would like to thank Richard Chiverrell and an anonymous reviewer. CC and TB publish with the permission of the Executive Director, BGS (NERC).

\section{Appendix A. Grain Size Analysis}

PSA involved oven drying samples at $50^{\circ} \mathrm{C}$ and wet sieving through a $62 \mu \mathrm{m}$ mesh sieve. The fine component was collected and left to settle in a 1000ml cylinder as detailed in Ingram (1971). Following settling, the distilled water was siphoned off and a proportion of the remaining sample was mixed with $100 \mathrm{ml}$ of $0.05 \%$ Calgon. After 24 hours a sub-sample was extracted, mixed with 100ml distilled water and analysed through the Beckman Coulter LS 130 Laser Diffraction Particle Size Analyser. For each sample, three repeats were completed to give the average size distribution. PSA of the remaining coarse fraction was determined through dry sieving at half Phi intervals for ten minutes (BSI, 1985).

\section{References}

Allmendinger, R. W., Cardozo, N., Fisher, D. M., 2012. Structural geology algorithms: vectors and tensors. Cambridge University Press.

Ballantyne, C. K., Stone, J. O., Fifield, L. K., 2009. Glaciation and deglaciation of the SW Lake District, England: implications of cosmogenic $36 \mathrm{Cl}$ exposure dating. Proceedings of the Geologists' Association 120 (2-3), 139144.

Barlow, D., Harris, E., McFarlane, A., 2009a. Windermere Fluvial Audit. Report A: Catchment Scale Geomorphology - Technical Report. Report to 
Environment Agency North West Region prepared by JACOBS Engineering UK Ltd. Tech. rep.

Barlow, D., Harris, E., McFarlane, A., 2009b. Windermere Fluvial Audit. Report B: Catchment Action Plan. Report to Environment Agency North West Region prepared by JACOBS Engineering UK Ltd. Tech. rep.

BGS, 1998. Kendal. England and Wales Sheet 39. Superficial deposits and Simplified Bedrock. 1:50 000.

Brown, V. H., Evans, D. J. . A., Evans, I. S., 2011. The Glacial Geomorphology and Surficial Geology of the South-West English Lake District. Journal of Maps,, 221-243.

BSI, 1985. British Standard 812-103.1 Testing aggregates.

Clark, C. D., Evans, D. J. A., Khatwa, A., Bradwell, T., Jordan, C. J., Marsh, S. H., Mitchell, W. A., Bateman, M. D., December 2004. Map and GIS database of glacial landforms and features related to the last British Ice Sheet. Boreas 33 (4), 359-375.

Clark, C. D., Hughes, A. L., Greenwood, S. L., Jordan, C., Sejrup, H. P., 2012. Pattern and timing of retreat of the last British-Irish Ice Sheet. Quaternary Science Reviews 44, 112-146.

Coope, G. R., 1977. Fossil Coleopteran Assemblages as Sensitive Indicators of Climatic Changes During the Devensian (Last) Cold Stage. Philosophical Transactions of the Royal Society of London. Series B, Biological Sciences 280 (972), 313-337. 
Evans, D. J. A., Livingstone, S., Vieli, A., O'Cofaigh, C., April 2009. The palaeoglaciology of the central sector of the British and Irish Ice Sheet : reconciling glacial geomorphology and preliminary ice sheet modelling. Quaternary science reviews. 28 (7-8), 739-757.

Hubbard, A. L., Bradwell, T., Golledge, N. R., Hall, A., Patton, H., Sugden, D., Cooper, R., Stoker, M., 2009. Dynamic cycles, ice streams and their impact on the extent, chronology and deglaciation of the British-Irish ice sheet. Quaternary Science Reviews 28 (7-8), 758-776.

Huddart, D., Glasser, N. F., 2002. Quaternary of Northern England. Vol. 25 of Geological Conservation Review Series. Joint Nature Conservation Committee, Peterborough.

Hughes, A. L. C., Clark, C. D., Jordan, C. J., 2010. Subglacial bedforms of the last British Ice Sheet. Journal of Maps 6 (1), 543-563.

Hughes, A. L. C., Greenwood, S. L., Clark, C. D., 2011. Dating constraints on the last British-Irish Ice Sheet: a map and database. Journal of Maps 7 (1), 156-184.

Ingram, R. L., 1971. Sieve Analysis. Wiley, New York.

Knight, J., 2001. Glaciomarine deposition around the Irish Sea basin: some problems and solutions. Journal of Quaternary Science 16 (5), 405-418.

Livingstone, S. J., Evans, D. J., Cofaigh, O., Davies, B. J., Merritt, J. W., Huddart, D., Mitchell, W. A., Roberts, D. H., Yorke, L., 2012. Glaciodynamics of the central sector of the last British-Irish Ice Sheet in Northern England. Earth-Science Reviews 111, 25-55. 
Livingstone, S. J., O Cofaigh, C., Evans, D. J. A., 2008. Glacial geomorphology of the central sector of the last British-Irish ice sheet. Journal of Maps, 358-377.

Lowag, J., Bull, J. M., Vardy, M. E., Miller, H., Pinson, L. J. W., 2012. High resolution seismic imaging of a Younger Dryas and Holocene mass movement complex in glacial lake Windermere, UK. Geomorphology 171$172,42-57$.

McDougall, D. A., 2001. The geomorphological impact of Loch Lomond (Younger Dryas) Stadial plateau icefields in the central Lake District, northwest England. Journal of Quaternary Science 16 (6), 531-543.

Miller, H., Bull, J. M., Cotterill, J. C., Dix, J. K., Winfield, I. J., Kemp, A. E. S., Pearce, R. B., 2013. Lake bed geomorphology and sedimentary processes in glacial lake Windermere, UK. Journal of Maps.

Millward, D., McCormac, M., Soper, N. J., Woodcock, N. H., Rickards, R. B., Butcher, A., Entwisle, D., Raines, M. G., 2010. Geology of the Kendal district - a brief explanation of the geological map. Sheet Explanation of the British Geological Survey. 1:50 000 Sheet 39 Kendal (England and Wales).

Pearsall, W. H., Pennington, W., 1973. Glaciation - The shaping of the landscape. In: The Lake District: a landscape history. Collins, London.

Pennington, W., 1943. Lake Sediments: The Bottom Deposits of the North Basin of Windermere, with Special Reference to the Diatom Succession. New Phytologist 42 (1), 1-27. 
Pennington, W., 1947. Studies of the Post-Glacial History of British Vegetation. VII. Lake Sediments: Pollen Diagrams from the Bottom Deposits of the North Basin of Windermere. Philosophical Transactions of the Royal Society of London. Series B, Biological Sciences 233 (596), 137-175.

Pennington, W., 1978. Quaternary Geology . In: Moseley, F. (Ed.), The Geology of the Lake District. Occasional Publication of the Yorkshire Geological Society. No. 3.

Pennington, W., Tutin, T. G., Bertie, D. M., 1977. The Late Devensian Flora and Vegetation of Britain [and Discussion]. Philosophical Transactions of the Royal Society of London. Series B, Biological Sciences 280 (972), 247 271.

Pinson, L. J. W., Vardy, M. E., Dix, J. K., Henstock, T. J., Bull, J. M., Maclachlan, S. E., 2013. Deglacial history of glacial lake windermere, UK: implications for the central British and Irish Ice Sheet. Journal of Quaternary Science 28 (1), 83-94.

Sissons, J. B., 1980. The Loch Lomond Advance in the Lake District, northern England. Transactions of The Royal Society of Edinburgh: Earth Sciences $71,13-27$.

Vardy, M. E., Pinson, L. J. W., Bull, J. M., Dix, J. K., Henstock, T. J., Davis, J. W., Gutowski, M., 2010. 3D seismic imaging of buried Younger Dryas mass movement flows: Lake Windermere, UK. Geomorphology 118 (1-2), $176-187$. 
Vincent, P. J., Wilson, P., Lord, T. C., Schnabel, C., Wilcken, K. M., 2010. Cosmogenic isotope $(36 \mathrm{Cl})$ surface exposure dating of the Norber erratics, Yorkshire Dales: Further constraints on the timing of the LGM deglaciation in Britain. Proceedings of the Geologists' Association 121 (1), 24-31.

Wentworth, C. K., 1922. A Scale of Grade and Class Terms for Clastic Sediments. The Journal of Geology 30 (5), 377-392.

Wilson, P., 2004. Description and implications of valley moraines in upper Eskdale Lake District. Proceedings of the Geologists' Association 115 (1), $55-61$.

Wilson, P., 2005. Paraglacial rock-slope failures in Wasdale, western Lake District, England: morphology, styles and significance. Proceedings of the Geologists Association 116, 349-361.

Wilson, P., Clark, R., 1998. Characteristics and implications of some Loch Lomond Stadial moraine ridges and later landforms, eastern Lake District, northern England. Geological Journal (2), 73-87.

Wilson, P., Clark, R., 1999. Further glacier and snowbed sites of inferred Loch Lomond Stadial age in the northern Lake District, England. Proceedings of the Geologists' Association 110 (4), 321-331.

Wilson, P., Smith, A., 2006. Geomorphological Characteristics and Significance of Late Quaternary Paraglacial Rock-Slope Failures on Skiddaw Group Terrain, Lake District, Northwest England. Geografiska Annaler. Series A, Physical Geography 88 (3), 237-252. 
Click here to download high resolution image

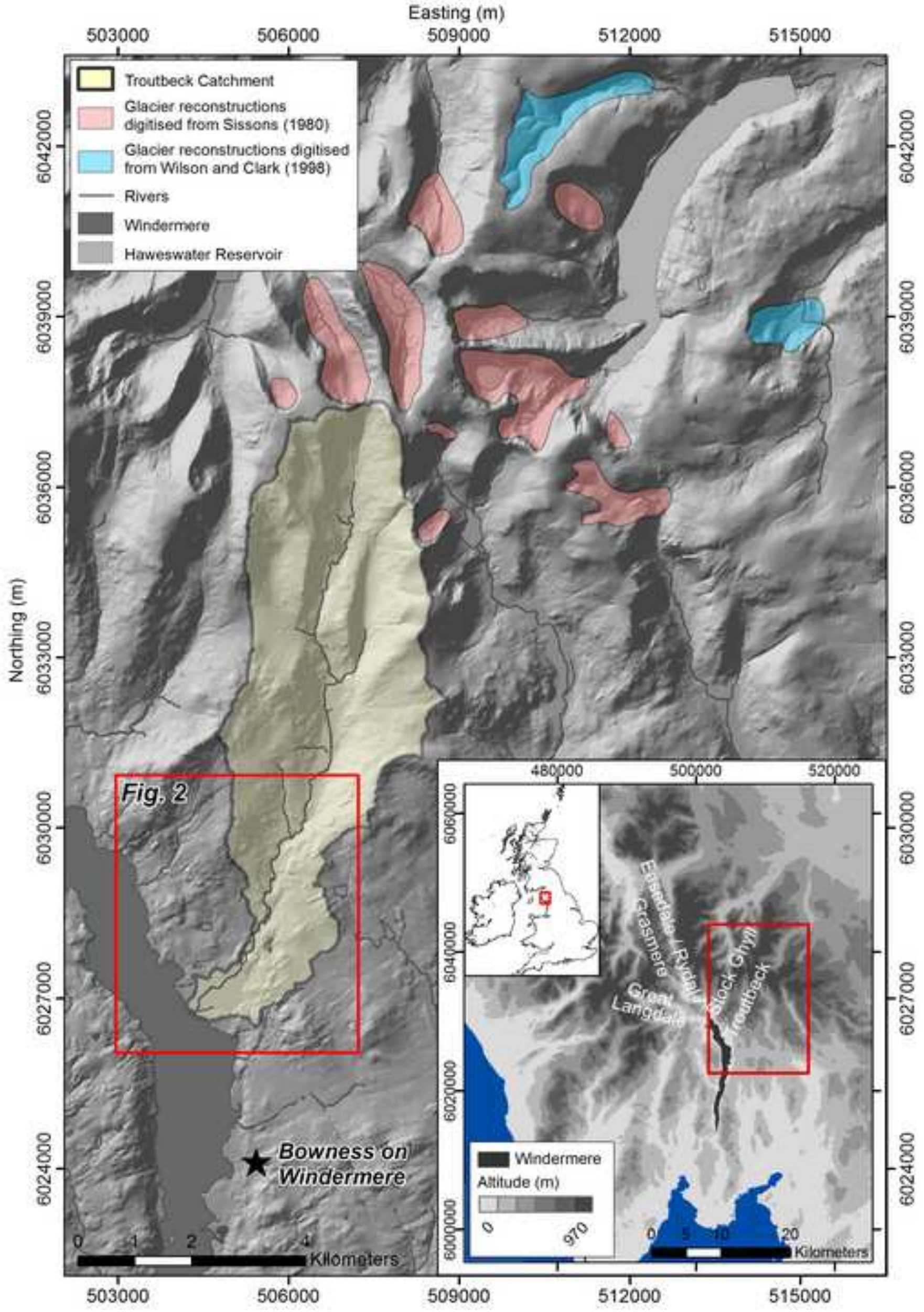




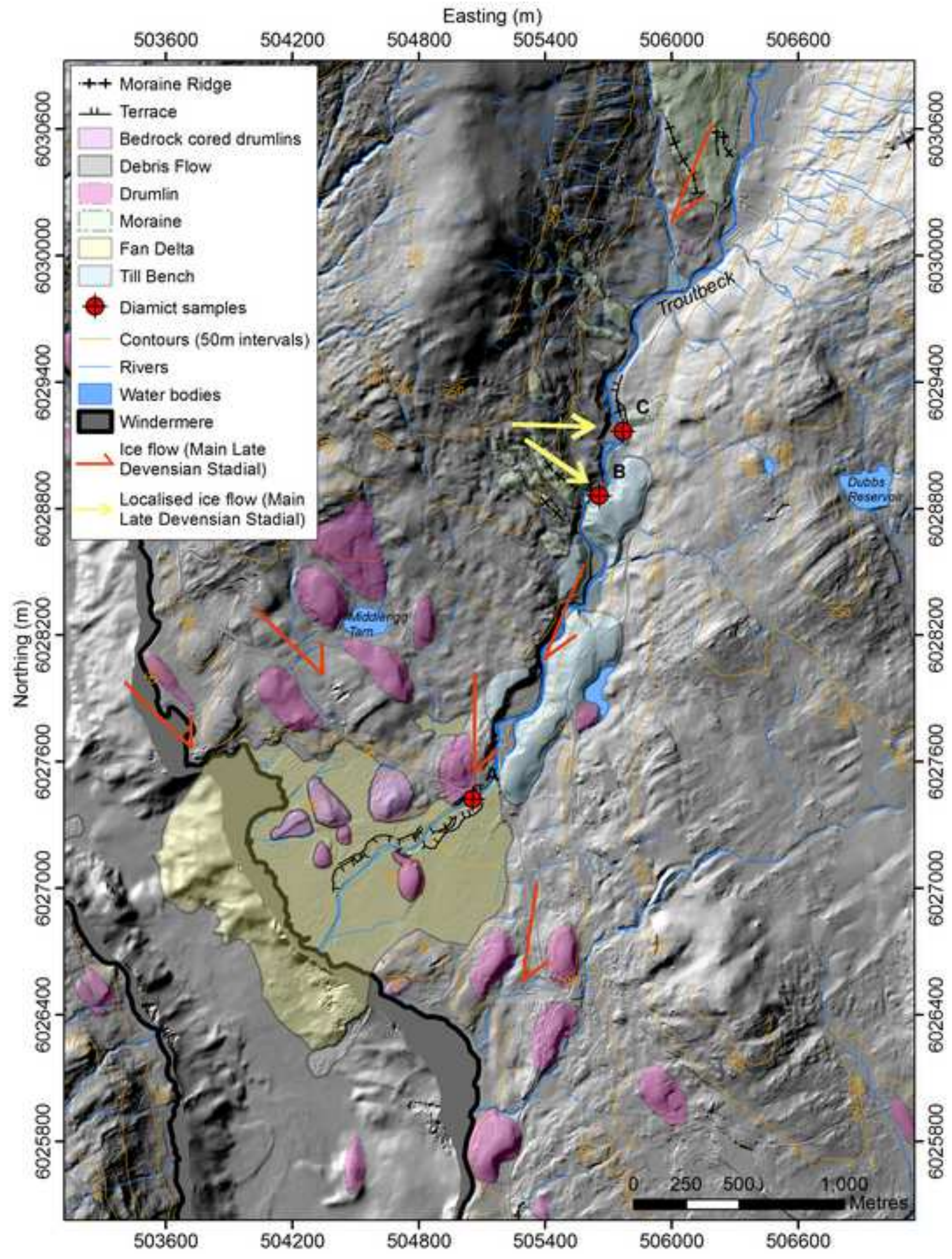


Figure 3
Click here to download high resolution image
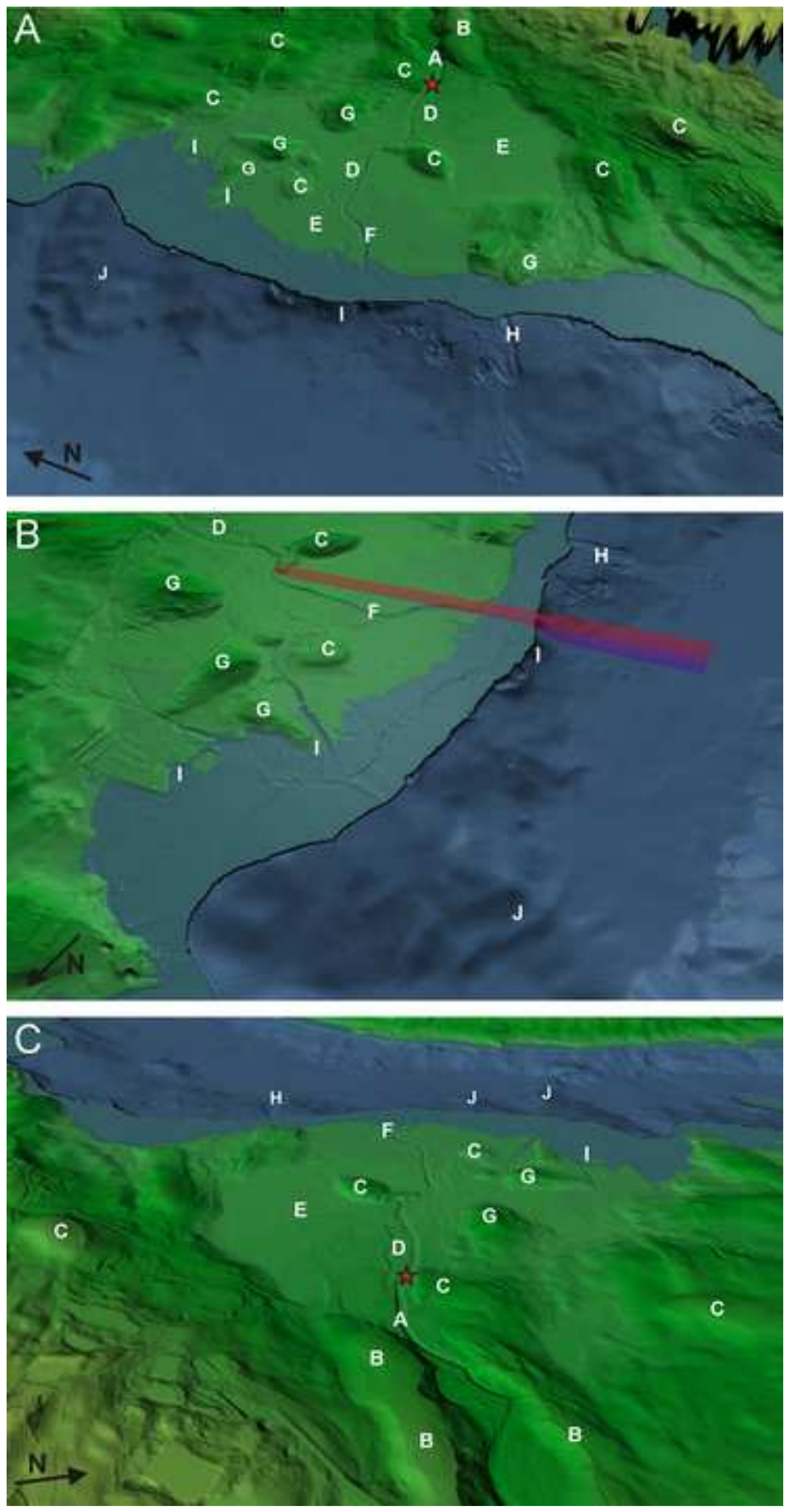
Click here to download high resolution image

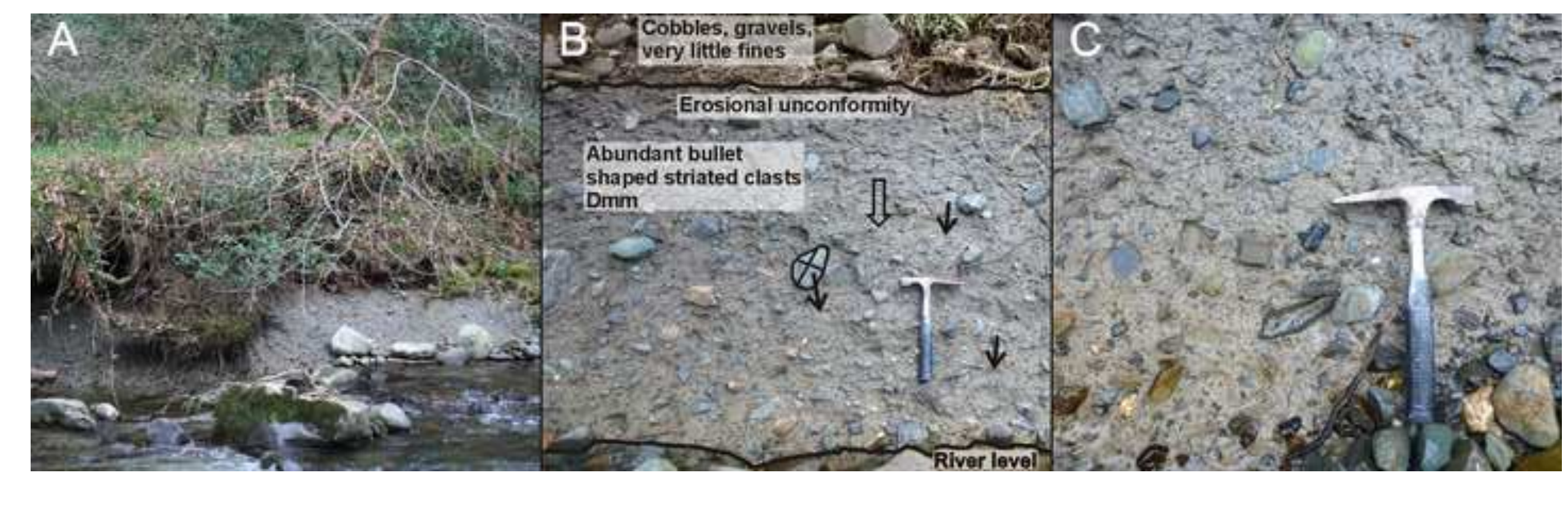



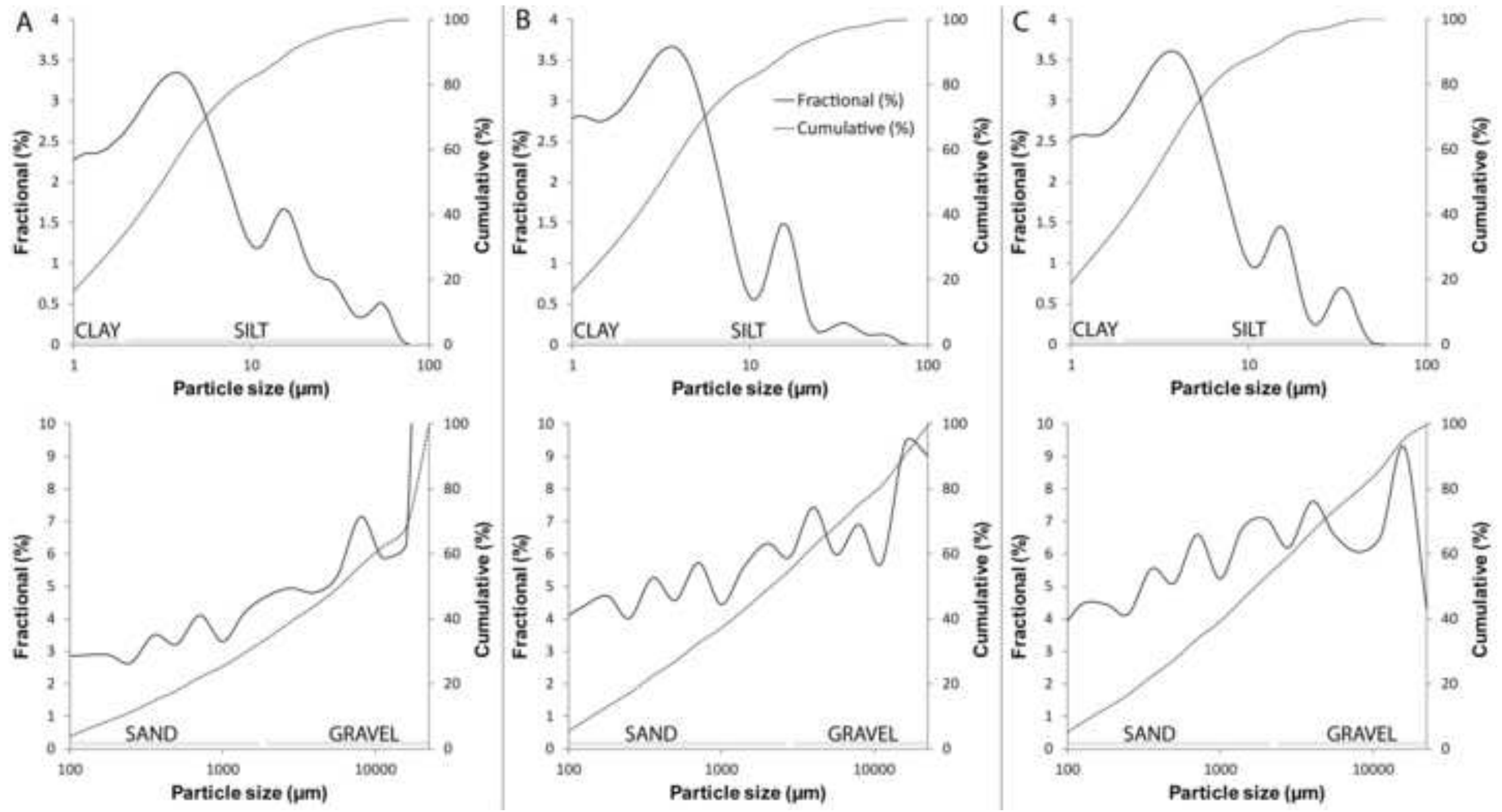
Click here to download high resolution image

A
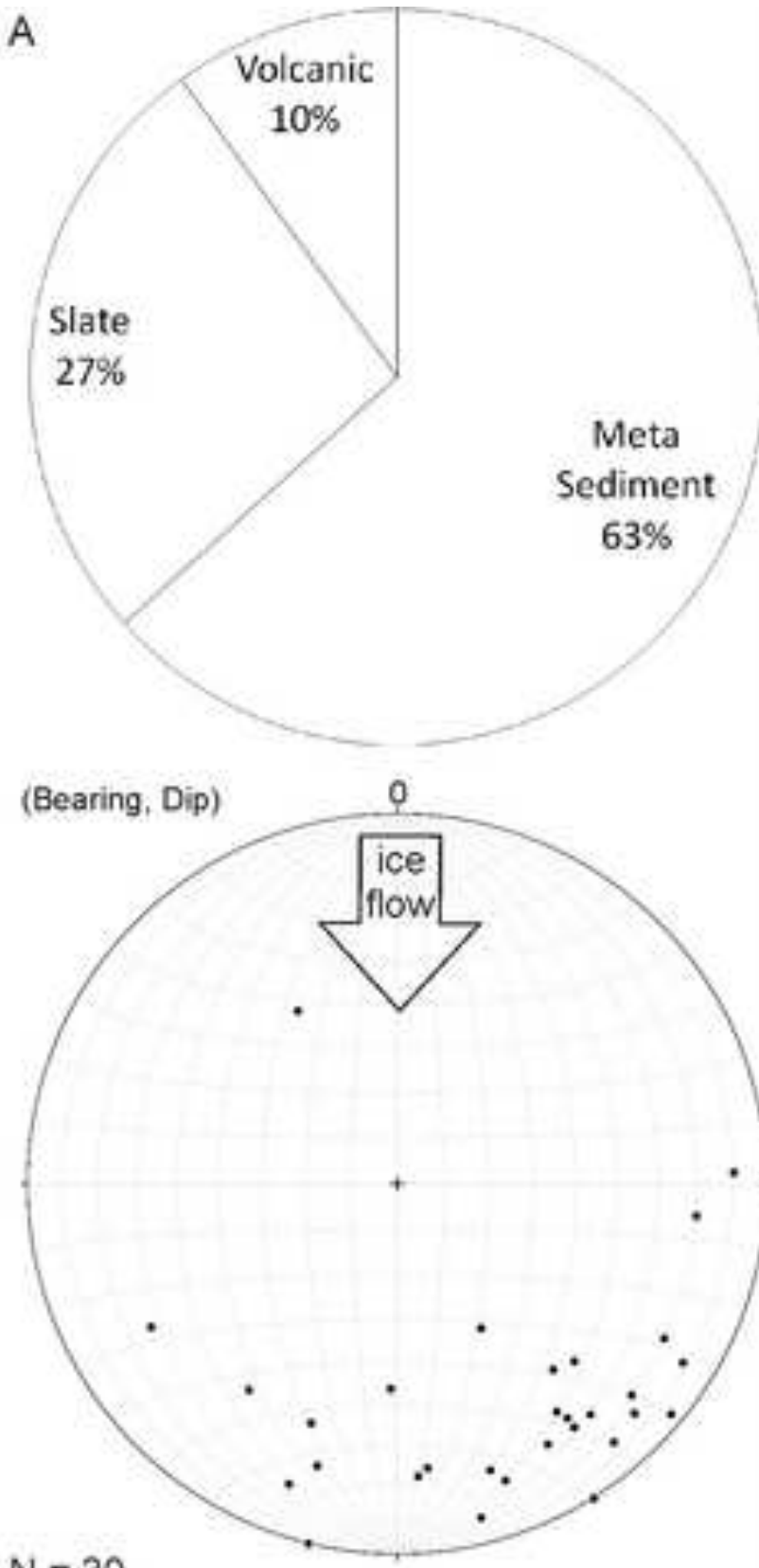

$\mathrm{N}=30$
B

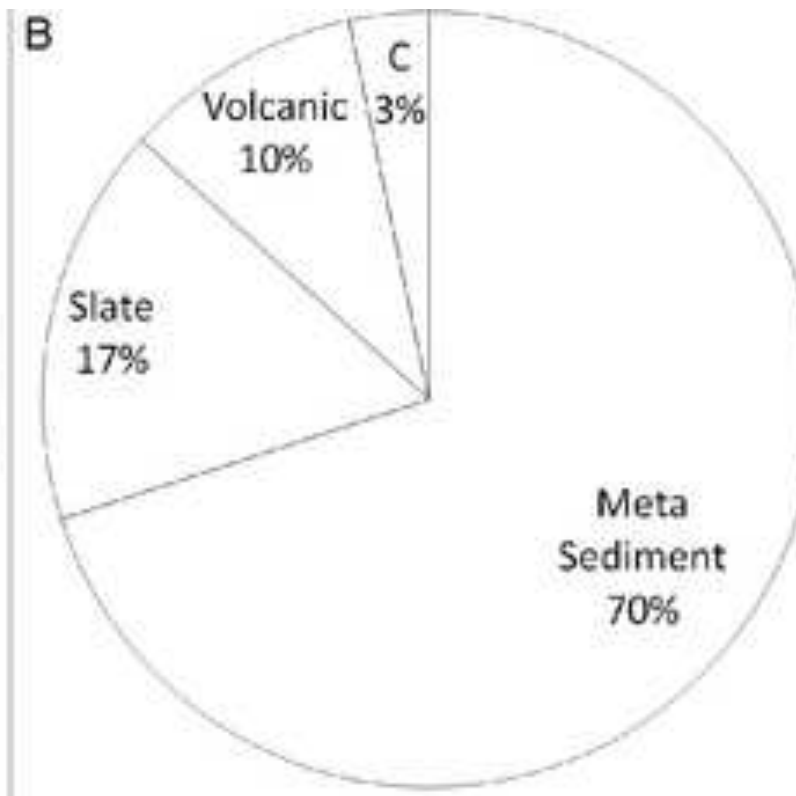

(Bearing, Dip)

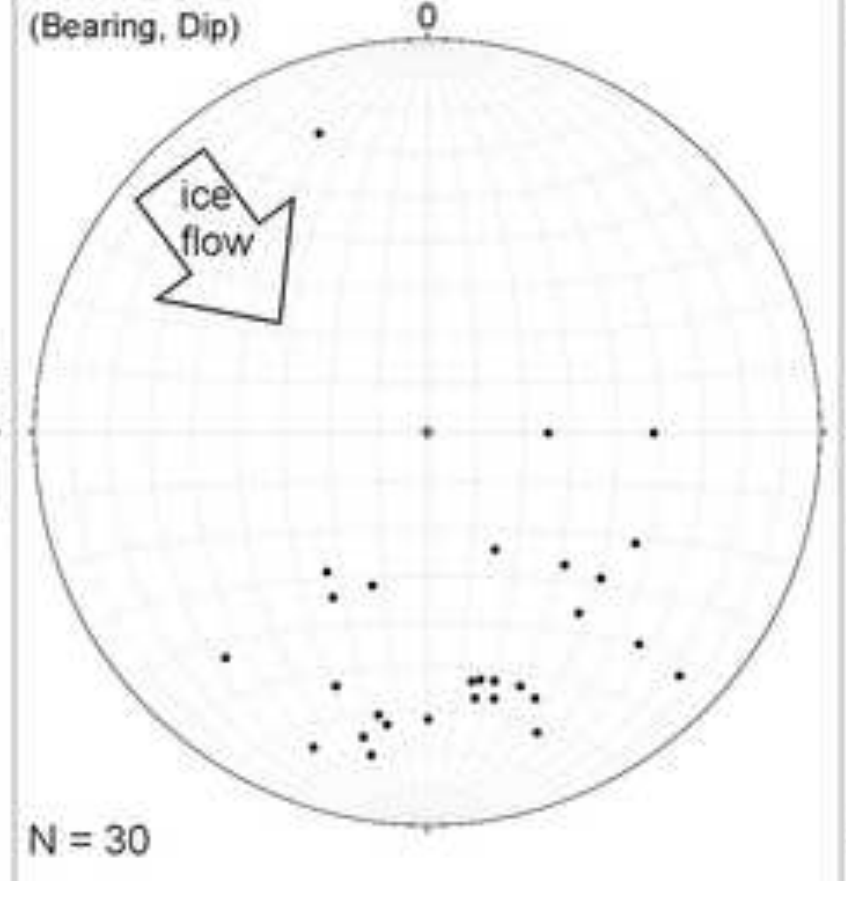

C
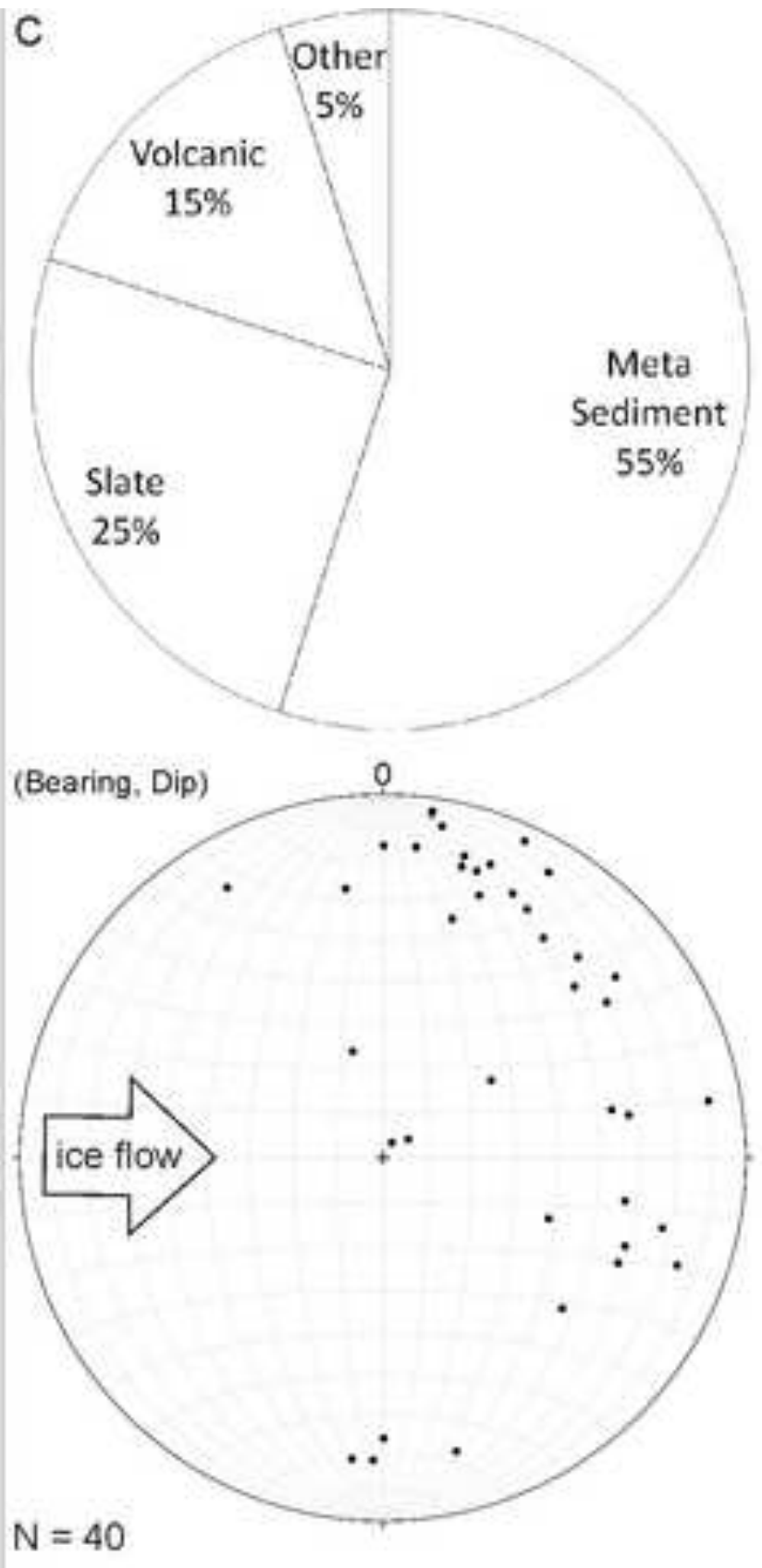
Click here to download high resolution image
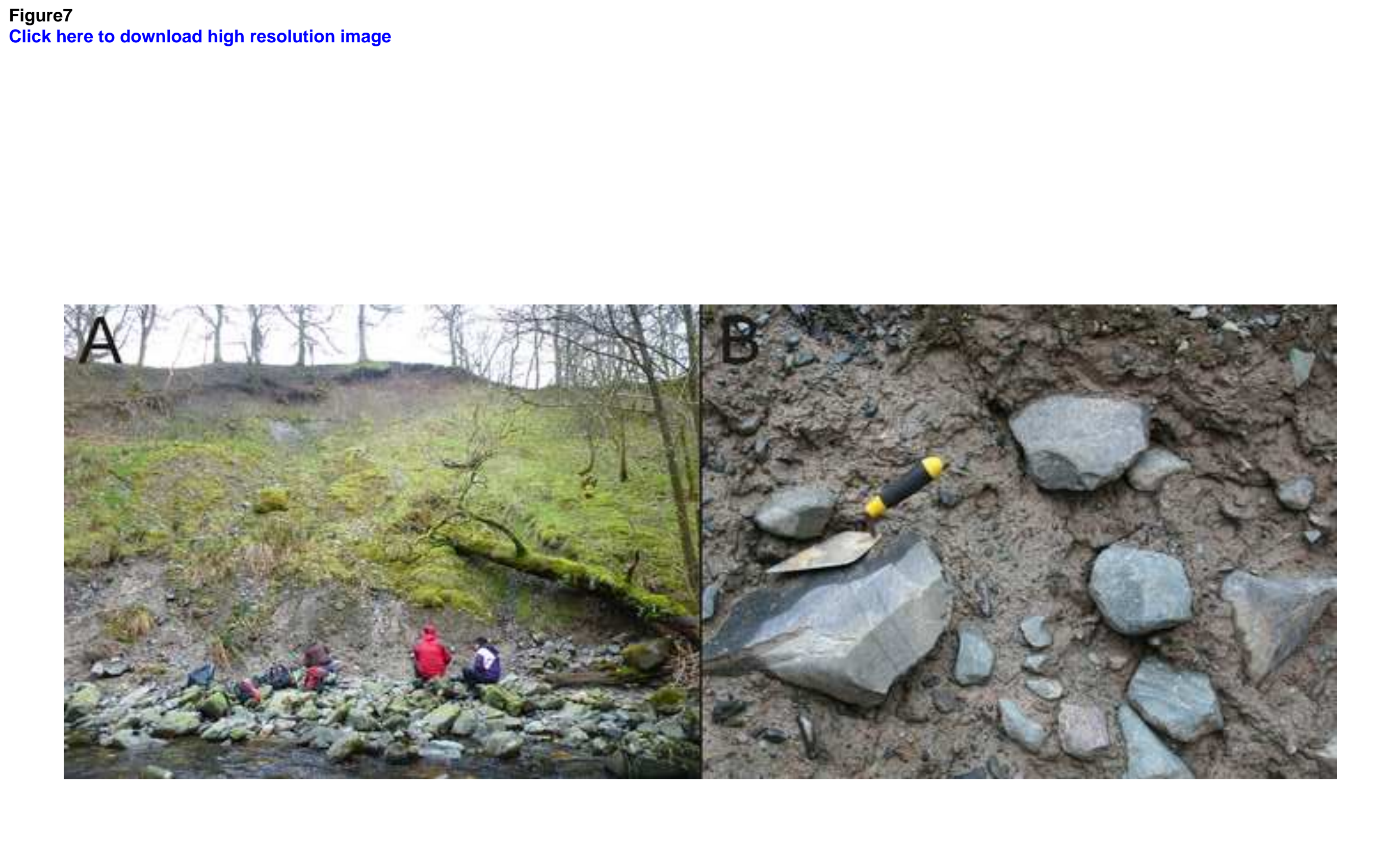

. 
